\title{
STRUCTURAL DA'WAH THROUGH PUBLIC POLICY (ANALYSIS OF DA'WAH ENCOUNTER AND GOVERNMENT LEGITIMACY IN INDONESIA)
}

\author{
Riza Anggara Putra \\ IAIN Ponorogo \\ Rizaanggara1993@gmail.com
}

\begin{abstract}
The discussion in this article focuses on the study of structural da'wah in public policy in Indonesia, which is currently widely used by local governments in various regions in Indonesia to improve morale and also campaign for Islamic values in their public policies. The focus of the discussion in this article is first, facts related to structural da'wah in Indonesia. Second, what is the background for the existence of structural da'wah in public policy in Indonesia, third, how is the formulation of structural da'wah in appropriate and good public policies. The fact related to how structural da'wah is mushrooming in Indonesia is that many regions apply structural da'wah in public policy. Various examples of regions in Indonesia that carry out structural da'wah in public policy are one of them in the Bulukumba area of South Sulawesi. As well as in Bandung Regency which has a structural da'wah program with the concept of Bandung Religious, a structural da'wah policy program is also implemented in the Central Java and East Java regions, namely in Jepara and Ponorogo Regencies. The emergence of structural da'wah policies in various regions in Indonesia cannot be separated from the existence of regional autonomy policy authorities. Concerning that local governments can regulate and manage their da'wah policies with their respective social structures. such as the degradation of morals and religious politics of the local government. In formulating the structural da'wah policy, the local government uses various innovations and various alternatives in formulating the da'wah policy. Structural da'wah policies must contain Islamic values and teachings that provide motivation, encouragement and an invitation to the Islamic community to implement and apply Islamic teachings as well as possible. The birth of this policy does not aim to make it an Islamic state and create a pure sharia-based constitution that is beneficial to society.
\end{abstract}

Keywords: Structural Da'wah, Public Policy

\section{INTRODUCTION}

Da'wah is the first main task of Rasulullah, he was sent by Allah SWT is to preach the teachings of Islam with full tenderness and a sense of peace. Historically, the Prophet carried out his da'wah mission using the Personal Approach or individual 
approach. First, he preached to his family secretly, followed by his da'wah approach being implemented to the public openly and openly. ${ }^{1}$

In the Indonesian context, the dynamics of the da'wah approach is usually carried out using a cultural da'wah approach or a da'wah approach from the lower classes of society. This of course cannot be separated from how past history recorded that Islam entered and spread in the archipelago by using a cultural da'wah approach. There are many ways or concepts such as cultural acculturation, arts and ta'lim assemblies that are successful in the mission of spreading Islamic teachings. However, with the development of the times, the cultural da'wah approach has very strong and diverse challenges. This is caused by social problems that occur in society. Globalization and technological developments whose negative effects have led to a massive increase in the number of immorality, moral degradation, rampant crime and various other negative actions such as action porn and pornography.

These challenges present a stigma and the assumption that cultural da'wah through the grassroots using the lecture and writing methods is seen as not being able to properly resolve social problems in society. It is on this basis that nowadays many regions in Indonesia strengthen the cultural da'wah approach by pre-ulama by using a structural da'wah approach.

The term structural da'wah is a concept of a da'wah approach that is carried out legally forma1 through a government structure or an institution. The background of the existence of structural da'wah cannot be separated from the interpretation of the legitimacy of the regional autonomy law which explains that regions have the right and power to regulate and manage their regions in accordance with applicable laws and regional governments also have authority in their efforts to develop regions, foster regional communities. and empowering local communities.

It is interesting to discuss and study about structural da'wah in public policy in Indonesia, which is currently widely used by local governments in various regions in Indonesia to improve morale and also campaign for Islamic values in their public policies. Second, what is the background of structural da'wah in public policy in 
Indonesia, third, how is the formulation of structural da'wah in appropriate and good public policies?.

\section{STRUCTURAL DAKWAH HEGEMONY IN PUBLIC POLICY IN INDONESIA}

The fact related to how structural da'wah is mushrooming in Indonesia is that many regions implement structural da'wah in public policy. Various examples of regions in Indonesia that carry out structural da'wah in public policy are one of them in the Bulukumba area of South Sulawesi. This area was the first to implement structural da'wah in public policy in South Sulawesi by implementing various policy breakthroughs, among others, zakat management, regulation of the ability to read and write the Koran for students and for prospective brides and grooms and prohibit the selling and distribution of alcoholic beverages.

Furthermore, there is the city of Bandung which has a structural da'wah program in public policy with the concept of Bandung Religious. This concept was initiated by Ridwan Kamil as the Mayor of Bandung. The mainstay program in structural da'wah in its public policy is the Ayo Koran movement, the morning prayer movement in congregation and the movement to pay zakat.

The next area that applies structural da'wah in public policy is in the Jepara area. The city of Jepara is a city that has a very strong religious nuance. Evidenced by the many things that have an Islamic nuance and the number of educational institutions that breathe Islam, be it Islamic Boarding Schools, religious schools, both formal and non-formal. Even according to data from 2015 to 2018, the city of Jepara became one of the areas with the largest number of educational institutions in the form of Islamic Boarding Schools in Central Java Province. ${ }^{2}$ Religiosity in the city of Jepara is also accompanied by a prestigious award from the central government as one of the regions that has a high concern for Islamic education. ${ }^{3}$

The city of Jepara also has various social problems. Various kinds of community problems are also very much there. This is because of the impact of

${ }^{2}$ Kanwil. Departemen Agama Provinsi Jawa Tengah. https://jateng.bps.go.id/ statictable/2017/04/12/1494/banyaknya-pondok-pesantren-kyai-ustadz-dan-santrimenurut-kabupaten-kota-di-jawa-tengah-2014-2015.html. Accessed at Friday, 30 Mei 2020 Pukul 13.58 WIB.

3 See at www.republika.co.id/berita/koran/internasional/koran/15/01/12/ni1vch1-tujuh-kepala -daerah-majukan-pendidikan-islam.Accessed at 30 May 2020 pukul 21.00 WIB. 
social change, the current of globalization and the rapid development of information technology related to moral degradation, juvenile behavior, criminal acts and other negative actions. As data, the number of juvenile delinquents in the city of Jepara is proven to be quite high, with a relatively high number of 190,195 cases. ${ }^{4}$

In Ponorogo, a structural da'wah policy was also implemented, the regent Ipong Muhlisoni as the first regent to launch the program let's go to bed, congregational morning prayers and regular recitations every week alternately in all sub-districts of Ponorogo.

Structural da'wah discussed in this article is like structural da'wah in public policies implemented by the Government of various regions in Indonesia. public policy.

\section{BACKGROUND OF THE EMERGENCE OF STRUCTURAL DAKWAH}

Along with the times, where people are trying to adapt to these developments and the government is trying to formulate various kinds of government agendas for the creation of good governance, religion is widely used as a solution option for society's problems. Especially now that various regions in Indonesia have their own authority to make regulations and manage their respective regions.

1. Social Problems

The social conditions of society that need to be changed in the Qur'an are expressed in several words, one of which is the word al zhulumat .5 The word al zhulumat according to commentators such as al Raghib al Ashfahani has two meanings, namely darkness and ignorance. Meanwhile, according to mufassir Muhammad Ali al Shabuni it has the meaning of stupidity, misguidance, and disbelief.6 A more detailed opinion is expressed by Sayyid Qutub as in his interpretation. He interprets that what is meant by al zhulumat is darkness due to wishful thinking, darkness originating from customs, darkness due to

${ }^{4}$ See http://isknews.com/190-149-remaja-jepara-rentan-masalah. Accessed at 30 may 2020, 20.15 WIB.

${ }^{5}$ In the Qur'an, the word al zulumat one of which is found in the letter Ibrahim verse 5 which means: And verily We have sent Moses with our verses, (And we ordered him), bring out your people (Moses) from darkness to light, and remember them in the days of Allah. Verily in that there are signs (of Allah's power) for everyone who is patient and much grateful. See Tafsirweb. Com. Accessed at Saturday, 1 june 2019, 19.30.wib.

${ }^{6}$ Muhammad Ali al Shabuni, Shafwah al Tafasir, (Beirut: Dar alquran al karim, 1981), cet. Ke-4, vol ke-2, p. 90-91. 
submission to many gods, darkness due to confusion in vision, values, and beliefs. considerations. ${ }^{7}$ In addition to al zhulumat, things that need to be changed according to the Koran are munkar, namely all actions that are considered bad by common sense or Islamic law.

Various areas that have been mentioned above including Bandung, Bulukumba, Jepara, Ponorogo indeed have a very good religious atmosphere. This can be proven by the number of formal and non-formal religious education institutions that are growing and developing such as formal schools and Madrasas, Diniyah Madrasas, Al Quran Education Parks, Islamic Boarding Schools, and so on. Although they have strong religious nuances, various regions also has social problems, especially those related to moral degradation, juvenile delinquency, and various other forms as a result of the negative impact of globalization and the rapid development of information technology. This is one of the motives of the local government in making several religious policies.

According to data from the Jepara Regency Government, 190,149 adolescents aged between 10-19 years in Jepara Regency are vulnerable to various kinds of social problems such as poor morality, high juvenile delinquency rates, and other negative things, one of the causes of which is the impact of globalization and developments. technology. ${ }^{8}$ These social problems are also dominant in the area of the Ponorogo district.

In Ponorogo, a reflection of these problems, for example, is how schoolage children who used to regularly recite the Koran after sunset began to leave the culture by watching television, playing gadgets, and hanging out on the roadside. In addition, in the afternoon the children used to study in religious institutions such as Islamic boarding schools, Al Quran Education Parks, and Madrasah Diniyyah began to decrease due to various factors such as no supervision and encouragement from the family environment, negative environmental influences and so on.

The development of science and technology in general causes changes in various aspects of human life, both in terms of social, religious, political, and

${ }^{7}$ Sayyid Quthub, Fi Zhilal alquran, (Kairo: Dar al Syuruq, 1992), vol. ke-4, p. 2085.

8 See http://isknews.com/190-149-remaja-jepara-rentan-masalah.Accessed at 1 June $2020,20.15$ WIB. 
community traditions. Globalization and advances in information technology have also brought enormous changes and changes in various aspects of the order of human life such as patterns of thinking, socializing, and behaving. Although this progress was able to bring about great and extraordinary changes, the Government of Ponorogo considered that progress had not been able to answer various kinds of problems in human life.

In the current era of globalization, all human activities rely a lot on technology. Of course this changes many things in people's lives, ranging from the economic, political, educational, and religious systems. Social conditions in the family environment in various regions in Indonesia have changed since the number of industrial factories that started emerging in the southern part of Jepara Regency which employs the majority of women. Under these conditions, many women work because of the support of the head of the family, helping the family economy and various other factors whose impact causes the supervision of children to be reduced because the majority of the fathers also participate. work. ${ }^{9}$

Social problems such as the existence of moral degradation, juvenile delinquency, crime, and political turmoil that exist in an area will influence or force policy actors to respond by including them on the government agenda which in turn gives birth to public policies to solve the problems concerned. According to systems theory, ${ }^{10}$ the making or birth of public policy cannot be separated from environmental influences. The demand for public policies is usually born due to environmental influences, and then transformed into a political system. The existence of structural da'wah in public policy in Indonesia cannot be separated from changes The order of values in society. This value order is a guideline and rules that are used as a reference and guide in assessing something and in controlling and choosing attitudes and morals in everyday life. The order of values. Values can also be interpreted as a collection of norms that

\footnotetext{
${ }^{9}$ Interview with Rini Susanti, in Ponorogo, Wednesday, 3 June 2020.

10 Thohir, Umar Faruq. Motivasi Jama'ah Lembkota Semarang dalam Mengikuti Pengajian Tasawuf. Diss. IAIN Walisongo, 2013.
} 
QAULAN, Vol. 2, No.2, Desember 2021

Riza Anggara Putra, Structural Da'wah...

are recognized by the community and are used as guidelines in determining the reality around them, and in determining subsequent attitudes. ${ }^{11}$

According to Tholhah Hasan, there are several factors that cause a shift in values in society such as advances in science and technology, economic progress and growth, political changes and the role of government power, changes in the biophysical environment, and the influence of foreign cultures. ${ }^{12}$ These factors can also be related to each other so that they give a greater degree of influence, both constructive and destructive value shifts. ${ }^{13}$

Actually, a change in the value system in society can have a positive impact if it is accompanied by self-discipline, being able to distinguish between what is useful and not, between those that contain maslahah and mafsadah. embedded in it collapses and the new values that replace it are not ready or their roles are not yet clear. This condition is generally experienced by people who are undergoing a period of transition, such as people in Ponorogo, Jepara and Bulukumba. ${ }^{14}$

\section{Religious Political Culture}

In the current reform era, the government or state provides broad space and accommodation for each group to organize and express opinions. In the era of regional autonomy, each region has the authority to a certain extent to manage its territory in accordance with the will of its people. This opportunity is used by the Regional Government to make public policies with Islamic nuances in the form of Regional Regulations that refer to Islamic law.

11 Samsul Munir Amin, Rekonstruksi Pemikiran Dakwah Islam, p. 56.

12 Technology and modern science have a reciprocal relationship. On the one hand, the results of science in the form of these theories are used by technology in formulating its models. While on the other hand, the results of technology in the form of products and processes are used by science. The dynamic aspect of science is the measuring experiments carried out by the objects, while the functional aspect is the theories that are made to explain the results of these experiments.. See Amrullah Amdad (ed), Dakwah Islam dan Transformasi Sosial Budaya, (Yogyakarta: PLP2M, 1985), p. 60.

13 The destructive impact is in the form of structural changes to the cultural order of society caused by the gap between the speed of development of technology and science and the speed of development of other parts of the cultural fabric of society, such as the flexing of social solidarity due to the abundance of materials brought about by industrial technology.. Muhammad Tholhah Hasan, Prospek Islam dalam Menghadapi Tantangan Zaman, (Jakarta: Lantabora Press, 2003), p. 13.

14 Samsul Munir Amin, Rekonstruksi Pemikiran Dakwah Islam, p. 60. 
Every society has a certain culture that distinguishes the values and lifestyles of its members from other members of society. In general, community culture can be referred to as a political culture that concerns behavior, values, and beliefs that are widely used as a guide for what the government should do and how the government should carry out its duties and responsibilities.

Da'wah policies that are realized through public policies in various regions in Indonesia depend on the politics of the Regional Head in determining the characteristics and patterns.

\section{THE PROCESS OF FORMULATING STRUCTURAL DAKWAH POLICY IN PUBLIC POLICY}

The process of formulating a structural da'wah is the first step in the concept of public policy. At this stage, it will be explained about structural da'wah through public policy in various regions in Indonesia with the policy formulation process which includes: problem formulation, structural da'wah policy formulation, policy determination, policy coverage content.

1. Problem Formulation

Problem formulation is an effort to identify existing problems and try to find out how these problems need to be made into policy-related problems and can be included in the government program agenda. ${ }^{15}$

A problem is categorized into two types, namely private problems and public problems. A problem can be said to be a private problem if the problem can be solved without affecting other people. On the other hand, if the problem is solved by intervention or influence from other people, it is called a public problem. Therefore, public problems can be understood as a result of not fulfilling the values, needs, or opportunities desired by the public and how to fulfill them requires policies from the government. ${ }^{16}$

In the stage of formulating the policy agenda, there are at least three things that need to be done by the government. First, building a perception

${ }^{15}$ Samsul Munir Amin, Rekonstruksi Pemikiran Dakwah Islam, p. 56.

${ }^{16}$ An example of a private problem, for example, is this, when the poor in the city find it difficult to buy rice because the price is rising and continues to soar, in fact this is part of a personal problem. However, when residents who suffered the same fate began to organize and make demands for the government to reduce the price of rice, the problem had shifted from a private problem to a public problem. Subarsono, Analisis Kebijakan Publik, p. 24. 
among stakeholders that a phenomenon is really considered a serious problem, because it may be a symptom or phenomenon in a community group that is considered a problem, but by some other people or political elites it is not considered a problem. Second, make the boundaries of the problem so that it can be directed clearly. Third, mobilize support so that these problems can be included in the government's agenda. Support mobilization can be done in various ways such as organizing groups in society, through political power, publication through the media, and so on. ${ }^{17}$

Problems that can be categorized as public problems are usually identical with various characteristics such as interdependence between various kinds of problems, subjectivity of policy problems, artificiality of problems, and dynamics of policy problems. A public problem is not a stand-alone problem, but there are interrelationships between one problem and another. In the aspect of interdependence, the problems that occur are classified according to the four policies initiated by the local government. The birth of the structural da'wah policy to turn off television after sunset accompanied by the Ayo Koran movement was motivated by moral degradation, and juvenile delinquency that occurred.

In the subjective aspect of policy problems, policy problems are the result of thinking in a certain environmental context, so that phenomena that are considered a problem in a certain environment may not be a problem in other environments. The problems that occur in Indonesia may only have dissimilarities with the problems faced by other environments.

In the artificiality aspect of the problem, a phenomenon is considered a problem because of the desire of humans to change situations and conditions. The existence of moral degradation, juvenile delinquency, the lack of children in religious education, the negative impact of globalization and the development of information technology are concerns of local governments, religious leaders and community leaders so that they have the initiative to overcome these problems and change the situation for the better. As for the dynamic aspect of policy problems, the solution to a problem often changes. The same problem may not 
necessarily be solved with the same policy if the environmental context is different. Likewise, the same problem may not necessarily be solved with the same policy if the time is different.

The problem formulation stage requires valid information and data so that the direction of the formulated policy can be directed and right on target. If the formulation of the problem is not supported by valid information and data, and only based on assumptions, it is feared that it will affect the accuracy of policy results.

\section{a. Adolescent Moral Degradation as a Public Problem}

Various regions in Indonesia in the social life of society, are known for various characteristics such as having a social life that knows each other between the citizens of the community, has a strong emotional bond, and has a high level of religiosity. social problems.

Adolescent moral degradation is one of the social problems that often occurs in various regions. In general, the moral degradation of adolescents in various regions occurs due to social deviations, the unbalanced development of globalization, the influence of foreign cultures, lack of parental supervision and attention, and low levels of education. Adolescent morals from year to year experience a decrease in quality or degradation in various moral aspects such as speech, dress, lifestyle, and so on.

The factor of family resilience is a factor that influences the moral degradation of adolescents in Indonesia. As the first foundation for children, parents actually play an important role in fortifying children from negative influences that can erode morals. Some of the things that are worried by the Regional Government are the increasing spread of moral deviations such as drinking, drugs, pornography, and so on.

b. Da'wah Policy A Government Agenda

Agenda setting is the process of scheduling public issues or problems into the policy process. This is intended so that public issues can be resolved through policy instruments. Public issues that have entered the setting agenda will be sorted through a priority scale with various other public 
issues. When a public issue is considered important with a fairly broad scope of impact, the public issue will be prioritized into a policy. ${ }^{18}$

Basically, agenda setting analysis is carried out to determine what should be done by the Regional Government as a policy maker. Hogwood and Gunn divide two stages of the agenda setting process, namely issue search related to the process and efforts to find issues to be set on the agenda. The other issue is the filtration issue, which is related to the process of sorting out issues. ${ }^{19}$ If in society there are debates and differences of opinion in seeing the nature of a problem, then the problem is seen as an issue. Therefore, the position of each stakeholder involved in the issue needs to be taken into account its interests, strengths, and tendencies. Each party has an influence on its ability to support or reject a policy.

The process of entering the issue in the agenda setting stage until it is formulated into a public policy is a fairly critical stage. At the stage of analyzing public issues to be included in the agenda setting, there is usually a tight competition between interests and forces in society. ${ }^{20}$ If the da'wah policy of the Government of various regions in Indonesia was originally an issue, then it was determined as a policy agenda.

The policy agenda can be stated as a list of issues that must be followed up. ${ }^{21}$ Edward explained that as a battle between interests, only a few issues were followed up. These issues are included in the policy agenda, usually by means of initiatives by policy makers, the presence of localities from parties outside the government, government-owned research institutions, individuals outside government organizations, or from the mass media. $^{22}$

2. Structural Da'wah Policy Formulation

18 Erwan Agus Purwanto, et.al., Mengembangkan Profesi Analisis Kebijakan, (Yogyakarta: Gadjah Mada University Press, 2015), p. 17.

19 Brian W. Hogwood and Lewis E. Gunn, Policy Analysis For The Real World, (USA: Oxford University Press, 1984), p. 5-6.

${ }^{20}$ Said Zainal Abidin, Kebijakan Publik, (Jakarta: Salemba Humanika, 2012), p. 85.

${ }^{21}$ Charles O. Jones, An Introduction To The Study of Public Policy, (North Scituate, Duxbury Press, 1977), p. 39

22 George C. Edwards dan Sharkansky, The Policy Predicament: Making and Implementing Public Policy, (San Fransisco: WH Freeman and Company, 1978), p. 100. 
The formulation of da'wah policy is how to develop options to solve various kinds of problems related to the negative behavior of the community and who later will participate in implementing the formulation of da'wah policies. This formulation stage discusses public problems that will be resolved using various policy alternatives. In decision making, there are various models of policy formulation carried out by actors to determine policy areas that are in accordance with the problems faced.

According to the theory of policy formulation, H.A.R. Tilaar and Riant Nugroho revealed that there are several concepts of policy formulation that can be used as a model such as institutional models (institutional), group models (groups), incremental (incremental), process models (process), rational models (rational), integrated observation models. (mixed scanning), system model, elite model, strategic model, game theory model, democratic model, deliberative model, public choice model, and garbage can model. ${ }^{23}$ Basically not all models of policy formulation will be used in analyzing how policy formulations are implemented by the Government of various regions in Indonesia in their da'wah policies.

Policy makers (policy making) in making decisions at least choose the best choice among the various models and decision-making techniques and know the choice of the best model. These models and decision-making techniques are used to analyze, find information, regarding various alternatives that exist to be used as a basis for decision making. ${ }^{24}$

The policy formulation process does not always produce policy objectives that match the intended goals. Policy makers or policy makers usually have political goals as well as personal goals that influence choices in determining the model of their policy area. Policy formulation is often equated with existing policies elsewhere, so there is policy diffusion in adopting similar

23 Riant Nugroho, Public Policy, (Jakarta: Elex Media Komputindo, 2017), p. 556.

24 Purwo Santoso, Modul Pembelajaran Analisis Kebijakan Publik, (Yogyakarta: PolGov, 2010), p. 84-85. 
policies from regions that are considered the most innovative in formulating policies. ${ }^{25}$

3. Policy Determination

Determination of policy is an attempt to later find out how alternative solutions to the da'wah policy are implemented and implemented, what are the criteria that must be met, who must implement the da'wah policy, what is the process or strategy in implementing and implementing da'wah policies and what are the contents of the da'wah policy that will later be will be applied. In terms of determining policy, one must understand two important aspects:

a. a. Understanding the Context of Da'wah Policy

Structural da'wah policies in various regions in Indonesia which were initiated by local governments contain many values of Islamic teachings that are encouraging, inviting and motivating the Islamic community to participate in implementing Islamic teachings properly. According to various sources, the birth of this policy does not aim to turn regions that implement da'wah policies into sharia regions or more specifically, do not intend to establish an Islamic state, only to create regulations that breathe Islam for the common good. 26

The influence of the implementation of da'wah policies in various regions in Indonesia is strongly influenced by various elements, such as historical elements, local political elements, and elements of religious social movements. The historical aspect is related to the character of various regions in Indonesia which have long been known for their level of religiosity. Various regions in Indonesia are known as countries that have strong religious nuances.

The political element is closely related to the contestation of power at the regional level. For a politician or incumbent who wants to run for regional head, the existence of religious policies as part of the vision and mission can be used as an effort to gain public sympathy and campaign events.

25 Anne Schneider, Policy Design and Transfer, Eduardo Araral, dkk (ed), Routledge Handbook of Public Policy, ( Newyork: Routledge, 2013), p. 219.

${ }^{26}$ Wawancara dengan Sudi Harianto, 12 april 2019. 
b. Values in decision making

Public policy is the government's choice to do or not to do, so that the definition according to Thomas Dye implies that public policy is part of a government product that contains choices about whatever the government should and should not do. Harold Laswell and Abraham Lincoln, as quoted by Subarsono argue that public policy should contain social goals, values, and practices that exist in society so that public policy should not conflict with social values and practices that exist in society. ${ }^{27}$

When decision makers adopt various models such as the group model, rational, and so on, then they certainly have a basis for making these choices. This means that decision makers have certain criteria to determine the approach used in the policy-making process.

Some decisions may be the result of available opportunities, carelessness, or not taking actions that make other actions effective, but the majority of actions taken involve the choices of policy makers. But the problem is the criteria or values. such as what influences these policy makers. To answer this question, of course, one is usually faced with various kinds of influencing factors such as political and social pressures, economic conditions, personal values of policy makers, and so on. ${ }^{28}$

1) Political values

Policy makers and makers may judge policy alternatives based on their personal or group interests.

2) Ideological Value

Policy makers and policy makers are usually influenced not only by political values, but also by ideological values, both personal and group ideologies. Ideology is a logically related set of values and beliefs that provides a simplified picture of the world and is a guide for carrying out various kinds of actions. ${ }^{29}$

${ }^{27}$ Subarsono, Analisis Kebijakan Publik, p. 2-3.

${ }^{28}$ James Anderson revealed that there are values that can influence and direct policy makers such as political values, organizations, policies, and ideologies. See James Anderson, Public Policy Making, (Newyork: Holt, 1969), p. 13-15.

${ }^{29}$ Budi Winarno, Kebijakan Publik: Teori dan Proses, (Yogyakarta: Medpress, 2008), p. 135. 
QAULAN, Vol. 2, No.2, Desember 2021

Riza Anggara Putra, Structural Da'wah...

Decision makers may act well on the basis of their perceptions and ideologies about the public interest or beliefs about what constitutes morally right and proper public policy, even though doing so carries political risks.

4. Contents of Policy Scope and Implementers of Da'wah

The contents of the policy coverage in da'wah activities are commonly referred to as da'wah materials or messages. Da'wah materials are messages in the form of Islamic teachings or everything that comes from the Koran and hadith that must be conveyed by da'wah actors to the object of da'wah. ${ }^{30}$ In general, da'wah material is classified into four main problems, namely the problem of faith, ${ }^{31}$ sharia problem, ${ }^{32}$ muamalah problem, ${ }^{33}$ and moral problems. ${ }^{34}$ And it does not aim to establish an Islamic region or state but seeks to live an Islamic life.

\section{CONCLUSION}

The fact related to how structural da'wah is mushrooming in Indonesia is that many regions implement structural da'wah in public policy. Various examples of regions in Indonesia that carry out structural da'wah in public policy are one of them in the Bulukumba area of South Sulawesi. This area was the first to implement structural

${ }^{30}$ Hafi Anshari, Pemahaman dan Pengalaman Dakwah, (Surabaya: Al Ikhlas, 1993), p. 140.

31 Akidah are things that are believed to be true by the soul, can bring peace and comfort to the heart, make strong beliefs that are not mixed with doubt. Akidah can also be interpreted as a number of issues that are generally accepted by humans based on revelation, reason, and human nature. See Tata Sukayat, Ilmu Dakwah, p. 26.

32 The implementation of the Shari'a is the source that gave birth to the existence of Islamic civilization, which protects and preserves it in history. Shari'a will become a strong civilization among Muslims. See Ismail R. Al Faruqi, Menjelajah Atlas Dunia Islam, (Bandung: Mizan, 2000), p. 305.

${ }^{33}$ Islam is a religion that pays attention to muamalah affairs with a larger portion than worship matters. Muamalah worship is worship that includes relationships with fellow creatures in the context of serving and worshiping Allah. Islam also pays more attention to aspects of social life than ritual life alone. See Tata Sukayat, Ilmu Dakwah, p. 27.

${ }^{34}$ Etymologically, morality means behavior, character, and temperament. According to Al Farabi, moral science is a discussion of various kinds of virtues that can convey humans to the highest purpose of life, namely happiness. Morals in Islamic teachings basically include the quality or quality of human attitudes and actions which are expressions of the condition of their souls. See Abdul Aziz Dahlan, Ensiklopedia Tematis Dunia Islam I, (Jakarta: PT. Ikhtiar Baru Van Hoeve, 2002), p. 190. 
da'wah in public policy in South Sulawesi by implementing various policy breakthroughs, among others, zakat management, regulation of the ability to read and write the Koran for students and for prospective brides and grooms and prohibit the selling and distribution of alcoholic beverages. , as well as in Bandung Regency which has a structural da'wah program with the concept of Bandung Religious, a structural da'wah policy program is also implemented in Central Java and East Java, namely in Jepara and Ponorogo Regencies.

The emergence of structural da'wah policies in various regions in Indonesia cannot be separated from the existence of regional autonomy policy authorities. With regard to that local governments can regulate and manage their da'wah policies with their respective social arrangements. The factor of the birth of the da'wah policy is strongly influenced by changes in the social order in society and social problems such as moral degradation and religious politics of the local government.

In the last stage, namely the formulation of structural da'wah policies, local governments use various innovations and various alternatives in formulating da'wah policies. Islam as best as possible. And the birth of this policy does not aim to make it an Islamic state and create a pure sharia-based constitution that is beneficial to society.

\section{REFERENCES}

Abdullah."Komplementaritas Dakwah Kultural dan Struktural", Jurnal Pemberdayaan Masyarakat, 2017.

Abdul Wahab, Solihin. Analisis Kebijakan :Dari Formulasi ke Penyusunan Model Implementasi Kebijakan Publik. Jakarta: PT. Bumi Aksara, 2016.

Amin samsul Munir.Ilmu Dakwah. Jakarta: Amzah, 2009.

Anderson, James. Public Policy Making. Newyork: Holt, 1969.

Edwards, George C. dan Sharkansky.The Policy Predicament: Making and Implementing Public Policy, San Fransisco: WH Freeman and Company, 1978.

Hogwood, Brian W. and Lewis E. Gunn. Policy Analysis For The Real World, USA: Oxford University Press, 1984.

Ilaihi, Wahyu. Dan . Munir M. Manajemen Dakwah. Jakarta: Kencana, 2012

Jones, Charles O. An Introduction To The Study of Public Policy, North Scituate, Duxbury Press, 1977.

Said Zainal Abidin.Kebijakan Publik. Jakarta: Salemba Humanika, 2012.

Santoso, Purwo. Modul Pembelajaran Analisis Kebijakan Publik, Yogyakarta: PolGov, 2010.

Shaleh, Abd. Rasyad Manajemen Dakwah Islam, Jakarta: Bulan Bintang, 1986. 
QAULAN, Vol. 2, No.2, Desember 2021

Riza Anggara Putra, Structural Da'wah...

Siagian, Sondang P. Manajemen Strategis, Yogyakarta: BPFE UGM, 1978.

Subarsono.Analisis Kebijakan Publik.Yogyakarta: Pustaka Pelajar, 2008.

Sukayat, Tata. Ilmu Dakwah. Bandung: Simbiosa Rekatama Media, 2015

Kanwil. Departemen Agama Provinsi Jawa Tengah. https://jateng.bps.go.id/ statictable/2017/04/12/1494/banyaknya-pondok-pesantren-kyai-ustadzdan-santri-menurut-kabupaten-kota-di-jawa-tengah-2014-2015.html. Diakses pada Jumat, 30 Mei 2020 Pukul 13.58 WIB.

Thohir, Umar Faruq. Motivasi Jama'ah Lembkota Semarang dalam Mengikuti Pengajian Tasawuf. Diss. IAIN Walisongo, 2013.

www.republika.co.id/berita/koran/internasional/-koran/15/01/12/ni1vch1-tujuhkepala -daerah-majukan-pendidikan-islam. Diakses pada 30 Mei 2020 pukul 01.00 WIB. 